\title{
Why Firms Perform Differently in Corporate Social Responsibility? Firm Ownership and the Persistence of Organizational Imprints
}

\author{
Yi Han ${ }^{1}$ and Enying Zheng ${ }^{2}$ \\ ${ }^{1}$ Shanghai University of Finance and Economics, China, and ${ }^{2}$ Cambridge University, \\ United Kingdom
}

ABSTRACT This article analyzes the effects of firms' founding ownership in shaping their corporate social responsibility (CSR) performance in China. Drawing on a nationwide survey of 1,037 representative manufacturing firms in 12 cities, we specify the imprinting effects of firms' founding ownership on labor and environmental protections, two important CSR practices. Our results show that state-owned enterprises (SOEs) founded during the state socialist period, regardless of their restructuring experience in the market reform era, continued to implement pro-labor practices. Moreover, even the SOEs founded in the market reform era provided better labor protection than non-SOEs founded during the same time. In contrast, the founding imprints of environmentalism in the reform era for non-SOEs, especially the de novo private firms, explain why they spent more than SOEs in environmental protection. We extend the organizational imprinting theory by highlighting the importance of firms' founding ownership imprints and in shaping their current CSR performance.

KEYWORDS corporate social responsibility, environmental protection, labor protection, organizational imprinting, ownership

\section{INTRODUGTION}

The organizational imprinting theory states that organizations' structures and practices are contingent on social resources and technologies available at the founding time of these organizations. The founding imprints continue to be important 'because of inertial forces such as tradition, vested interests, or ideology, or because of a lack of competition' (Stinchcombe, 1965: 169). Prior research has studied imprinting effects in localized interlocking board networks (Marquis, 2003), location-specific financial logics or rationalities (Lounsbury, 2007), founders' experience (Baron, Burton, \& Hannon, 1996; Baron, Hannon, \& Burton, 1999a, 1999b; Burton \& Beckman, 2007; Beckman \& Burton, 2008; Ding, 2011), market 
environments (Boeker, 1988, 1989a, 1989b), banking practices (Marquis \& Huang, 2010), and small network structures (Sullivan, Tang, \& Marquis, 2013). Most of these studies have focused on external environmental factors during firms' founding period, while less attention has been paid to firms' internal organizational features and how they serve as vehicles in preserving organizational imprints.

One understudied organizational feature by organizational imprinting scholars is the state ownership of business firms. In socialist countries, state-owned enterprises (SOEs) have played a particularly important role (Kogut \& Zander, 2000; Kriauciunas \& Kale, 2006) in shaping realms of economy and management. Since communist parties took power, they created a unique state ownership to fulfill both economic and social functions. During the earlier socialist period, SOEs followed the state demand, not the market order, to determine the production and distribution flow (Lin, Cai, \& Li, 1998). The nature of SOEs profoundly differs from that of firms in capitalist economies.

The transition from planned economy to market economy of former socialist countries posed great challenges to SOEs. The market economy differs from the state-commanded logics and practices, and generates debates over SOEs' identities and boundaries. The administrative strength and cultural mobilization of a socialist state set up a founding stage with the deeply-seated routines and mentalities for SOEs. The pro-market transition, however, constitutes an important sensitive period with a distinct market and institutional environment, which may exert new imprints and partially replace socialist founding imprints.

To reform SOEs has been a goal in transition economies and is meant to move from state control to the invisible hand of market order. Once SOEs were forced to take up new rules in a market economy, they had to search for clues and information elsewhere to fill in their knowledge gaps. In their research, Kriauciunas and Kale (2006) showed that if former SOEs in Lithuania learned from other firms located remotely from the former socialist alliance, they would overcome socialist liabilities and succeed in making the transition. Unlike other former socialist countries that went through 'shock therapy', some Chinese SOEs still remain state-owned and are able to maintain their economic and social influence after more than three decades of economic reform. Moreover, despite a continuing change toward a flexible labor market and more managerial autonomy since economic reform, a recent corporate social responsibility (CSR) movement brings to light the lingering effects of socialist founding imprint of pro-labor practices.

Understanding organizational imprints of SOEs throughout various historical periods is critical, because it leads to a proper diagnosis of firms' actual capabilities and deficiencies and leads to solutions for better management and effective policy makings. To better understand firms' compliance with CSR requirements, a historical perspective on firm founding and post-founding sensitive periods is necessary. We also need to examine the effects of different founding periods on firms of different ownerships to illuminate the processes by which organizational imprints are maintained or altered. 
Drawing on the organizational imprinting literature, we study the effects of SOEs' socialist founding imprints and the subsequent restructuring experience in the economic reform era on their current CSR performance in China. To establish that an imprinted pattern exists, we analyzed firms' compliance with two CSR practices in 12 cities as of 2005: their expense on labor and environmental protection. To explain how an imprinted pattern came into being and became institutionalized, we traced SOEs' founding environments to the early 1950 s and their subsequent restructuring experience in the 1990s. We compared SOEs' performance in labor protection with that of private firms and FIEs founded during the market reform. Because private firms and FIEs faced a founding environment that was characterized by emerging environmentalism but relaxed labor regulations, they might be more responsive to environmental protection than most SOEs founded during the socialist period.

Our research makes several important contributions to the organizational imprinting and CSR literatures. First, it states the importance of firm-level (in addition to previously studied social-environmental level) organizational features in preserving organizational imprints and in selectively adopting CSR practices. Second, it restates the importance of founding period (versus later sensitive periods) of firm ownership. Firms of the same ownership are more likely to adopt certain CSR practices legitimatized by institutions activated in their ownership founding time and are less likely to be influenced by institutions activated in other sensitive periods. By studying CSR through the lens of the organizational imprinting perspective, our research also reveals the fact that different CSR practices are rooted in different historical eras, which explains why firms of various origins may put different emphasis on various dimensions of CSR, e.g., labor or environmental protection.

The rest of this article is as follows. We first summarize prior research on organizational imprinting in general and socialist imprinting in particular, and theorize how socialist ownership imprints matter. We then incorporate the ownership imprinting argument with a well-established literature on Chinese industrial relations and recent studies of the CSR campaign to generate our research hypotheses. Next, we describe our research methods, followed by empirical results. We conclude this article by summarizing empirical findings and theoretical contributions, and discussing future research.

\section{THEORETIGAL BACKGROUND AND HYPOTHESES}

\section{Founding State Ownership and Sensitive Periods}

Stinchcombe's (1965) seminal argument about organizational imprinting stated that organizations are historically contingent on, and reproduce the characteristics of, their founding environment. Despite a growing literature on varying imprinted 
features and at different levels (see Marquis \& Tilscik, 2013 for a review), the organizational imprinting argument has been mainly developed from and applied to the US context, where institutional and market environments have remained relatively stable over the past several decades, in spite of technological development in transportation and communication. This relative stability itself tends to strengthen the effects of founding imprints, as no subsequent fundamental changes have challenged the routines and principles established during a founding period. Under such circumstance, empirical research had difficulties in assessing whether and how post-founding environments would undermine founding features. An empirical setting with fundamental transformations in multiple domains in a short period of time could help to address the concern whether the persistence of founding imprints is due to a pure lack of subsequent environmental changes and hence founding features still fit the current environment, or because of some other mechanisms such as a localized template and late comers' emulation (Marquis, 2003).

Transition economies of former socialist countries can be a fertile ground for unpacking founding organizational imprints. Although many other countries have experienced a variety of shocks to their economies such as hyper-inflation in Latin America or currency collapse in Southeast Asia in the 1990s, the transition economies are unique in that 'multiple environmental and systematic changes occurred at the same time' (Kriauciunas \& Kale, 2006: 663). As a consequence, SOEs founded during the socialist period faced a significantly different business environment and economic system from the one they were used to operating in. Several pioneering studies have analyzed the effects of socialist organizational imprinting on firms' strategies and capabilities in transition economies. For example, Kriauciunas and Kale (2006) showed that the knowledge and know-how of former SOEs that reflected their founding socialist institutional and market legacies might adversely impact their ability to adopt market-oriented operating knowledge. Such socialist liabilities, however, could be meliorated through learning from firms operating in market economies (Kriauciunas \& Kale, 2006: 674). The founding stage is an important and special sensitive period for an organization. However, there exists more than one sensitive period, for an organization's development, or during an individual's life course (Marquis \& Tilscik, 2013). For example, an acquisition or merger represents a major event for a firm and thus creates a sensitive period for its existing and new members to navigate new rules, identities, and routines (Marquis \& Huang, 2010). During these sensitive periods, organizations or individuals are exposed to external shocks and have to renegotiate meanings, rituals, and rules that may differ from their initial conditions.

Firm ownership is a contested area in transition economies. Due to their low efficiency, SOEs are to be reformed, either by restructuring or through mergers and acquisitions. For many people with experience working in SOEs in a socialist period, they had taken for granted lifetime employment, housing, social securities, and community services provided by their employers. Take China as an example. 
Since the Chinese Communist Party (CCP) took power in 1949, it nationalized the economy and all firms became state- or collectively-owned in the early 1950s. Typically, when urban residents graduated from middle school or vocational training school, they were assigned by the local bureau of labor to an SOE and then received on-the-job training under the supervision of a veteran worker. Permanent employment was guaranteed, because a firm was interpreted as belonging to the country and everybody, not to management. Medical, retirement, and children's education was basically free. This type of industrial relations system gave rise to the deeply-seated belief that SOEs functioned as a social and political organ rather than an economic actor.

Not all socialist legacies are necessarily liabilities. Kogut and Zander's (2000) study of the Zeiss Company in Germany revealed that the socialist imprints on firms' technological innovations may be constrained in a market environment. Based on patent and archival data analysis, they found that the state-owned Zeiss Jena in East Germany started to allocate more resources on R\&D in the electronics sector in the 1980s in response to a mandated guideline by the (then) East German government instead of the market demand. This early move to the electronics sector, however, provided accumulative knowledge and know-how regarding the emergent semiconductor and laser areas in the 1990s. As a matter of fact, it outperformed its counterpart in West Germany that was merged into the same corporation following the fall of the Berlin Wall.

Examining former SOEs' adaptation to a market economy in a transition economy, Kriauciunas and Kale (2006) discovered the liabilities of the socialist imprinting while Kogut and Zander (2000) found some positive effects of the socialist planning system on innovative capacities. Moreover, even for the same SOEs experiencing the transition, some areas or attributes are relatively easier to change than others, especially when external resources become available and accessible. In contrast, some complex and internal issues may have experienced stronger imprinting effects. Because collectivist mentality of socialist regimes gave primacy to features such as SOEs' training programs and egalitarian wage system (Kriauciunas \& Kale, 2006: 674), such institutional environments may remain relevant and become reproduced in a transition economy. Labor-management relationship is certainly a fundamental aspect of a firm's daily operation and a significant feature of SOEs. It involves legal regulation, societal values, and institutionalized practices. Once established, it is very likely to become embedded in organizational identities or imprinted on founders' blueprints (Baron et al., 1996, 1999a, 1999b, 2001; Beckman \& Burton, 2008; Burton \& Beckman, 2007). Given the fact that socialist states are good at mobilizing resources to enforce their policies, founding imprints shaped during a socialist period, especially those relevant to institutions (vis-à-vis market), may be more difficult to change. State ownership, historically and collectively constructed by the strong state power and practiced by a large number of former SOE employees, is a key organizational feature in socialist and transition economies. 


\section{GSR Performance and Different Founding Imprints}

Debates over firms' CSR practices have caught the attention of various groups such as business press, political leaders (Buhr \& Grafstrom, 2004), academic researchers (Lockett, Moon, \& Visser, 2006; Margolis \& Walsh, 2003), unions, and professional managers (Marquis \& Qian, 2013; Pedersen, 2010). Although what constitutes CSR has not reached a consensus (Davis, Whitman, \& Zald, 2008), labor and environmental protection have been identified and examined by scholars (Bartley, 2007). For example, the United Nations' Global Compact launched in 2000 is one of the earliest and most prominent voluntary initiatives for corporations to show their commitment to labor and environmental protection. Nine out of its top ten principles are related to labor rights and environmentalism.

With respect to the factors driving firms' compliance with CSR initiatives, some highlighted institutional pressures such as state regulation and client monitoring (Campbell, 2007; Locke, Qin, \& Brause, 2007), and others argued for a stakeholder perspective that includes local communities, employees, and other social actors in a synthetic framework (Hoffman, 2001; Schofer \& Hironaka, 2005). Despite some important findings, prior research has focused its analytic lens onto firms' ongoing institutional pressures, but left the historical sources of practice variation under theorized (Lounsbury, 2001). Some studies of organizational and national cultures do tackle the issue of historical influences on current organizational features, and regard cultures as historically constructed (Victor \& Cullen, 1988). This strand of research, however, did not provide details about how the past continues to influence the present and whether various historical periods have left different imprints on organizations' current practices. Addressing this theoretical concern, below we will describe how different founding stages corresponded to firms with different ownerships in China, and how founding ownerships have a lasting effect on their current CSR practices in labor and environmental protection.

\section{SOEs and Socialist Imprinting of Labor Protection}

As an important aspect of the CSR campaign, labor standards could be analyzed through a perspective of the industrial relations system, which has a unique socialist legacy in China. Since the CCP took power in 1949, three time periods are noteworthy. Each period is characterized by a distinct industrial relations system with a correspondingly different understanding of the nature of firms and the labormanagement relationship. The underlying rhetoric and practices speak to their degrees of resemblance to today's CSR campaign with regard to labor standards.

The first stage started in the early 1950s and lasted until the early 1990s. Beginning in the early 1950s, the CCP government started a series of social engineering programs with a focus on nationalizing industries and commerce. All firms became state owned, although the levels of government commanding firms' operations varied from the central government to a township government. 
For employees, once they were assigned to a work unit by the local government, they were provided with lifetime employment, were covered by workplace safety and insurance, and given a pension and benefit package (Walder, 1986).

The second period was between the early 1990s and the mid-2000s when the socialist legacies of protective labor relations, carried out by SOEs, became contested and restructured as China extended its economic reform to the state sector. For most SOEs, this was a sensitive period with a distinctly different institution in comparison to their founding stage. The discourse of efficiency, flexibility, and low cost competition emerged in association with the massive SOE restructuring effort (Hurst, 2009). A noticeable fact is that a large proportion of former SOE employees were laid off without proper compensation during this process. ${ }^{[1]}$ The sole ownership of the state became dispersed with certain shares acquired by private and foreign investors. Some SOEs were restructured into private firms or FIEs. While this period constitutes a sensitive period for many SOEs founded during the socialist era, it is also a founding stage for a large number of newly established private firms and FIEs. Both types of firms competed for the global export market on low cost and flexibility. Economic efficiency and a flexible labor market characterized these firms' founding stage, during which there lacked strict legal regulation on labor protection (Lee, 2007).

The third stage from the mid-2000s to the present is a turning point, when contentious industrial relations have become fateful to the stability of the Chinese state and a more pro-labor institutional environment is taking shape. Multiple forces have exerted pressure on firms in China aiming to improve labor standards. In response to consumer pressures, multi-national companies (MNCs) have begun to request that their Chinese contractors and suppliers comply with global labor standards such as minimum wages and zero tolerance of child labor (Locke et al., 2007). The Chinese state has also begun to enforce labor standards more seriously, indicated by the Labor Contract Law and the Labor Dispute Mediation and Arbitration Law, which took effect in 2008. Despite the state and transnational private labor regulation, its effects remain limited (Locke et al., 2007; Xu \& Li, 2012). Nevertheless, this general change in a pro-labor environment coincided with the rise of CSR practices. CSR practices in relevance to labor standards resemble some of the social functions performed by SOEs during the first stage.

Figure 1 delineates the number of firms founded per year by their ownership, ranging from 1955 to 2000, based on information from a representative national sample that we will describe in detail in the following section. The difference between SOEs and non-SOEs in labor standards revealed the effects of their different founding environments. Admittedly, there are differences between de novo private firms and de novo FIEs. In our research setting, most de novo private firms and de novo FIEs were founded in the second stage, during which forging a flexible labor market without much government intervention or contract protection was preferred and practiced. Some de novo FIEs joined the 'race-to-the-bottom' by deliberately investing in developing countries where labor legislation is weak and regulation is 


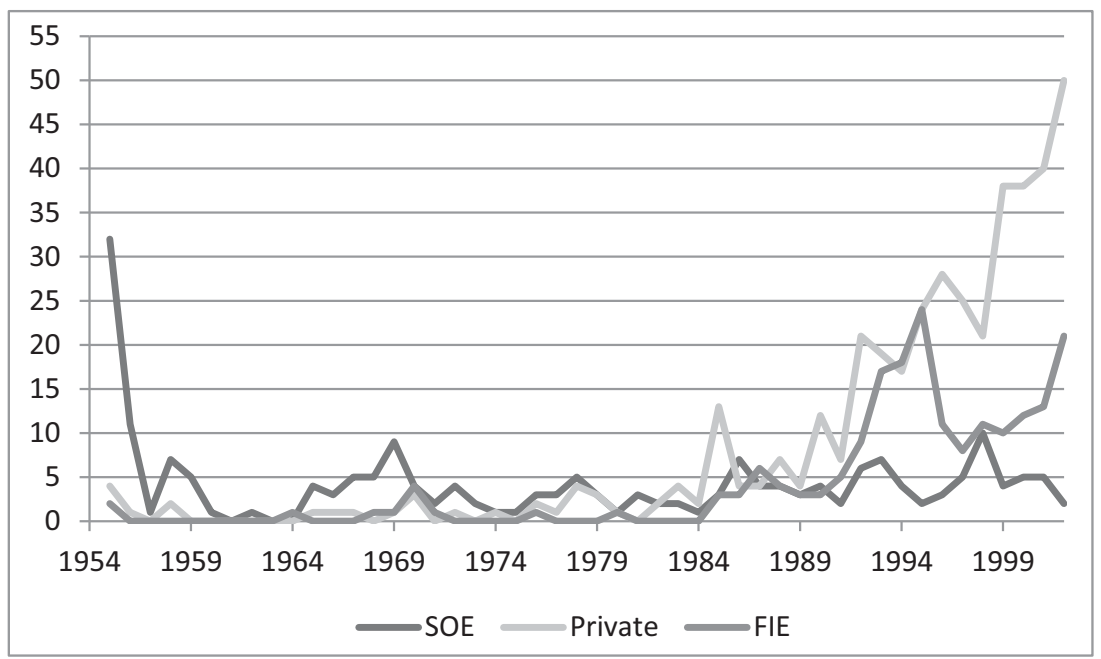

Figure 1. Number of firms established per year by ownership

Source: China Survey Data Network, Private Sector Survey (2006). The authors collected information on firms' founding years in 2011.

loosely enforced (Frazier, 2010; Khanna \& Palepu, 2000). In this regard, we treated de novo private firms and de novo FIEs similar to each other and contrasted their responses to labor standards with that of SOEs. In summary, firm ownership in our research setting corresponded to the two different founding periods: most SOEs founded in the socialist period and almost all de novo private firms and de novo FIEs founded during the subsequent market reform period.

Tilcsik (2014: 640) argued for 'imprint-environment fit' which refers to the degree of congruence between the initial, formative context and subsequent conditions. According to (Tilcsik, 2014), initial experiences are likely to leave a persistent imprint on newcomers' skills, habits, and routines, and this imprint is formed in, and will be best suited to, a particular type of resource environment. One entrenched perception by Chinese people is that SOEs tended to treat their workers well, engage in their communities and social life, and offer lifetime employment. When an ambiguous CSR movement emerged to address labor problems, firms tended to learn from their past experiences in the earlier socialist period. As Tilcsik (2014) notes, because there is a high degree of fit between the early resource context (the first stage) and a subsequent one (the third stage), SOEs' imprint of labor standards is likely to be compatible with the current environmental demands. For most SOEs, their unique founding legacies in labor protection found a match with the current institutional environment, making them more likely to engage in labor protection.

Some SOEs founded in the first stage were restructured during the second stage. Thus, it raises a reasonable question regarding whether the restructuring experience has changed SOEs' socialist imprints. Three factors suggest a strong imprinting effect of socialist founding ownership on SOEs' persistent pro-labor practices. 
Firstly, employment relationship as an important organizational feature is often institutionalized and internalized through shared beliefs, cultural mobilization, and routines. Baron and his colleagues' series of research (Baron et al., 1999a, 1999b; Hannan et al., 1996) demonstrated strong effects of the founding employment model, or what they called 'blueprints or cultural script' on new ventures' management system. These blueprints fundamentally shaped management practice at the time of founding and the subsequent periods.

Secondly, the socialist founding period itself has a particularly strong imprinting effect and becomes the most sensitive period. In their study of the Lithuanian transition economy, Kriauciunas and Kale (2006) distinguished the socialist market environment from institutional environments and found that the latter was more entrenched and difficult to change during the market transition. In particular, the knowledge set related to training programs and wage systems was much less successful in transformation than other knowledge sets, such as marketing and the development of product or service lines. An underlying reason is that training programs and wage systems are more internal to firms and people-oriented in terms of their attributes, and therefore much more difficult or slower to change (Kriauciunas \& Kale, 2006).

Finally, although the number of SOEs has decreased significantly, their influence in the Chinese economy is still prevalent. Over time, Chinese SOEs learned technological know-hows and other operational experiences from firms in market economies in the context of employment relationship that is deeply rooted in national cultures. However, there is no such readily available template that offers a hands-on or more codified experience for SOEs. For the restructured Chinese SOEs, if they could not effectively engage in learning from external sources such as western firms, they could draw on their own past. In this regard, we have the following hypothesis:

Hypothesis 1: SOEs founded in the state socialist period, regardless of subsequent restructuring experience in the market reform period, will have better labor protection than non-SOEs.

Even as the socialist planning system gradually gave way to a market-oriented reform, central and local governments founded some new SOEs from scratch. For the newly founded SOEs during the second period, they faced a similar founding environment to that of de novo private firms and de novo FIEs. For these new firms, a generic understanding of the same founding conditions, however, overlooks the firm-level differences. Prior studies of organizational imprinting in the western context pointed out the roles played by founders in leaving imprints on organizations in a variety of settings (Burton, 2001; Beckman, 2006; Ding, 2011; Simons \& Roberts, 2008). The de facto founder of SOEs is the Chinese state. The state control over economy and the society through SOEs remains fairly stable.

Moreover, when new SOEs were founded during the market reform period, top management teams were selected, trained, and monitored by the state. Most of these managers and their government supervisors accumulated first-hand experiences 
from their prior work in SOEs. When they were in charge of a newly founded SOE, it made more sense for them to learn from their past experiences. Even some relatively young managers joined SOEs who did not have direct experience of socialist imprinting; most of them certainly grew up in a community and received early education provided by their parents' employers - the SOEs founded in the socialist period. Their childhood memories could be further strengthened and activated by their senior colleagues in the newly founded SOEs. It is similar to secondhand imprinting, which means that individuals are influenced by social conditions that existed even before their careers began, through socializing with senior colleagues (Tilcsik, 2014).

Finally, the state ownership of firms itself as a special organizational form has a homogenizing effect on new SOEs. McKendrick and Carroll (2001) regarded organization form as a bundle of prominent characteristics of an organization that identify it as a distinct entity. A locally legitimating organizational form to some extent could reproduce its prevalence. For example, Marquis (2003) found that local networks of board members in the US corporate community left a founding legacy, even though transportation and communication technologies have provided more opportunities to include non-local board members. Similarly, Simons and Roberts (2008) examined the evolution of the Israeli wine industry and found that new organizational forms are hard to penetrate in extant populations, and novelty is more likely to be adopted if founders had work experience in non-local organizations. In our setting, the founders (or more accurately, the top managers) of newly founded SOEs were usually appointed from governments or other SOEs who have enough local knowledge. We thus expect that the newly founded SOEs would still behave the same as the older SOEs founded during the socialist period but quite differently from non-SOEs founded during the market period. These factors together suggest that:

Hypothesis 2: SOEs founded during the market reform period will have better labor protection than non-SOEs founded in the same time.

By emphasizing the founding imprints of the socialist state ownership, we are not to call for a retreat to the previous institutional environment and non-market conditions. Here, we use SOEs as an empirical example to illustrate the strong socialist imprinting effects in labor protection. We argue that Chinese SOEs carry unique founding imprints in pro-labor behaviors, regardless of their founding eras and restructuring experiences. We also want to make it clear that SOEs are not perfect in the area of improving labor standards, but they perform relatively better than non-SOEs in this regard because of their unique founding imprints.

\section{Environmentalist Imprints for Non-SOEs}

The rapid growth of China's economy in the past three decades comes with enormous environmental costs. Environmental protection that originated from 
western societies has become another essential CSR practice in China since the late 1990s. Both international and domestic stakeholders have played a crucial role in driving firms' compliance with environmental standards (Hoffman, 2001; Marquis et al., 2011; Schofer \& Hironaka, 2005). For instance, non-governmental organizations (NGOs) and social media are becoming increasingly important in shaping firms' environmental disclosure in China. As an independent civil society force, these NGOs are able to grasp emergent opportunities offered by the internet and transnational activist networks (Yang, 2005). Stakeholders' and customers' environmental movements also start to play an important role, as evidenced by a number of reports in social media outlets. The Chinese state has also allocated considerable resources on promoting environmentalism. In 1998, the State Environmental Protection Administration (SEPA) was promoted to the ministry level and was officially designated as a governmental agency in charge of environmental issues. The 2002 Environment Impact Assessment Law and the 2006 Renewable Energy Law targeting firms all signal the state determinacy in improving environmental standards (see Marquis et al., 2011 for details).

Without a historical precedent in China, procedures, techniques, and legal regulation of environmental standards were new concepts for all firms and their mangers regardless of ownership type. In this regard, environmental protection is a crucial institutional factor characterizing the newly founded firms during the market reform period, including new SOEs, de novo private firms, and de novo FIEs. Unlike labor protection initiated in the socialist era, there have been no such founding imprints of environmental protection among the SOEs founded in the socialist period. Although the subsequent reform era is one sensitive period for those SOEs, it remains less influential in shaping their practices than their founding environment. In addition, as mentioned above, the main theme for SOEs during this sensitive period was to maximize profits and to get rid of all non-economic activities. When the organizational principles dominating the socialist period were challenged, SOEs as a carrier of this template tended to reject their social responsibilities including their commitment to environmental protection. This generated stronger resistance to any non-business related responsibilities such as environmental protection. As our argument for the labor protection suggests, even for the SOEs that were founded in the socialist period and were later restructured during the market reform, they tended to behave similarly to their counterparts without restructuring experience. Together, the SOEs founded during the socialist period were less influenced by the environmental protection pressure than the de novo private firms and de novo FIEs, which were founded during the market reform period. Thus, we have the following hypothesis:

Hypothesis 3: SOEs founded in the state socialist period, regardless of subsequent restructuring experience in the market reform period, will have worse environmental protection than non-SOEs.

Although environmentalism emerged in the 1990s and is an important founding characteristic for firms founded during the market transition period, firms of 
different ownerships may understand and respond to it differently. There is mounting evidence that because private firms in China lacked political and social legitimacy, they tended to spend considerably more resources to signal their compliance with institutional requirements. For example, empirical studies found that domestic private firms donated more money to charities than other firms (Ma $\&$ Parish, 2006). As such, private firms with low status and weak bargaining power may have greater incentives to comply with environmental protection. Although FIEs in general have higher status and richer resources than private firms, the former may have a full knowledge of their relative superiority and become more vigilant of environmental movements (Zhao, 2012). As a consequence, both private firms and FIEs may be more willing than SOEs to address environmental issues to avoid being targeted.

\section{Hypothesis 4: SOEs founded during the market reform period will have worse environmental protection than non-SOEs founded in the same time.}

In summary, ownership is a key organization-level feature that guides firms of the same ownership type to behave similarly, even though they were founded in different historical eras. Taking SOEs (including restructured SOEs) as focal organizations, we argue that the founding period is the most sensitive period in shaping firms' present features and practices. The founding ownership imprints during the socialist period have enabled SOEs - regardless of their restructuring experience in the subsequent reform period - to outperform private firms and FIEs in labor protection. Private firms and FIEs' founding imprints during the economic reform and global competition period have rendered greater compliance with environmental standards than SOEs, even in comparison with the newly founded SOEs.

\section{METHOD}

To test our hypotheses, we employed a dataset compiled through a large-scale survey of Chinese firms in 2006. In 2011, we collected additional information on these firms, such as their founding ownership structures and their restructuring experience. In order to test the enduring imprinting effects on firms' C.SR performance, our data analyses unfolded in three stages. First of all, we compared SOEs founded in the state socialist period (before and in year 1992), which did not undergo restructuring, with non-SOEs founded in the market reform period. Secondly, we compared the restructured SOEs founded in the socialist period with non-SOEs to further test the effect of socialist imprinting despite dramatic changes in sensitive periods. Finally, we compared SOEs founded in the market reform period (after year 1992) with non-SOEs to test the effect of socialist ownership imprinting. We did not hypothesize, but explained briefly different subcategories of SOEs that would behave similarly in terms of their CSR performance. 


\section{Data}

The original dataset was generated by the China Survey Data Network (CSDN). In the CSDN survey, managers from different departments of a given firm answered different questions pertinent to their primary tasks, such as a firm's financial performance, governance structures, product quality management, labor conditions, and environmental protection. The initial dataset included 1,268 industrial firms from 12 provinces in China. Each firm was asked to provide its information for the years 2004 and 2005. To reduce the likelihood of endogenous explanations, we lagged independent variables for one year in all the regression models: we measured independent variables using the information provided for year 2004 and measured dependent variables using the information provided for year 2005.

Among these 1,267 firms, there are 1,131 (89.3\%) manufacturing firms, defined by Industry Classification Codes from the Statistical Bureau of China (national standards number: GB/T 4754-2002). Of these 1,131 firms, nineteen firms failed to provide information on our primary independent variable (e.g., ownership). Seventy-five firms failed to provide information on our dependent variables, i.e., their CSR practices in labor and environmental protection. We therefore focused our data analysis on the remaining 1,037 firms.

Dependent variables. The dataset contained information on firms' actual spending (e.g., RMB, in 10,000 Yuan unit) on labor and environmental protection. In the CSDN survey, human resource managers were asked to provide information on firms' actual expenditure on labor protection such as safety-related training and equipment. We used this information to measure firms' CSR practices in labor protection. In the survey, production managers were asked to fill out the questionnaire regarding firms' operation costs on environmental protection. There were two relevant questions: 1) the cost that is related to paying fines and spending on auditing; and 2) the cost that is related to their investment in the devices for environmental protection in the last three years. We added those two types of expenditures to measure a firm's CSR practices in environmental protection. The voluntary spending on environmental protection indicates firms' efforts in environmental protection. However, it is also possible that some firms spend more on environmental protection because they are emitting more waste water and gas and, thus, they are required to pay fees; in order to remedy this problem to some extent, we controlled sectors within the manufacturing industry in the regression analyses.

We took the logged form of the dependent variables. Since the minimum values of both dependent variables are 0 , we added 1 to each case before we took the log.

Independent variables. Accounting for the firm-level variation in CSR practices, scholars have used ownership (Guthrie, 1999; Locke et al., 2007) to reflect a 
wide variety of institutional and economic factors that might be relevant. Because we were also interested in firms' founding conditions, we manually searched for information on the founding ownership of each of these 1,037 firms. Among these 1,037 firms, 237 were initially founded as SOEs, 570 were founded as private firms, and there are 230 FIEs. The numbers of firms founded each year by ownership type is show in Figure 1. Among the 237 SOEs, 148 were founded before and in 1992, the year the Chinese government officially embraced the market economy after the former leader, Deng Xiaoping's, famous speech in the city of Shenzhen; 89 were founded after the mass market transition. For those SOEs founded before 1993, 80 underwent restructuring, while 68 remained intact. In total, we identified five ownerships for the purpose of hypothesis testing and statistical robustness check: de novo private firms, de novo FIEs, old SOEs (founded before 1993) without restructuring experience, restructured SOEs (founded before 1993), and new SOEs (founded in and after 1993). Whenever necessary, we merged the old SOEs and restructured SOEs to reflect their socialist founding imprint in state ownership. These categories were treated as dichotomous variables in our statistical analyses.

Control variables. Because institutional pressures have been important for the diffusion and enforcement of firms' CSR practices, we included relevant institutional factors. For example, it has been well-studied that the transnational private regulation carried out by large MNGs is a key factor in improving labor standards (Bartley \& Child, 2011; Locke et al., 2007). In response to consumer boycotts and the 'naming and shaming' campaigns, many MNCs have hired external auditors or dispatched their own officers to examine their suppliers' labor standards in China before economic transactions. In the survey, marketing managers were asked whether their foreign clients had required them to meet labor standards. In a similar fashion, the managers were also asked whether the foreign clients had required them to meet environmental standards. The answers to these two questions were two dichotomous variables that measured transnational private regulation, an important source of institutional pressures. Specifically, we used the clients' requirement on labor standards to predict firms' expenditure on labor protection, and used the clients' requirement on environmental standards as a predictor of firms' expenditure on environment.

State regulation is another important source of institutional pressure that may influence firms' CSR practices. The power of state regulation is salient in China, where the government has been playing a significant role in economic activities. In the survey, marketing managers were asked to report the number of government inspections per year on labor and environmental protection, respectively. We used the answers to these two questions as measurements of institutional pressures from the state. Both variables were treated as continuous variables in the statistical analyses.

In addition to institutional pressures, we controlled for firm specific factors, such as the number of employees and profit (e.g., continuous variables). We controlled for 
Table 1. Summary of variables

\begin{tabular}{|c|c|c|c|c|c|c|}
\hline Variable & Obs & Mean & S.D. & Min & $\operatorname{Max}$ & Description \\
\hline Log_Labor & 1037 & 5.29 & 2.41 & 0 & 12.76 & $\begin{array}{l}\text { Firms' expenditure on labor } \\
\text { protection in } 2005 \text {, logged }\end{array}$ \\
\hline Log_Env & 873 & 3.02 & 1.98 & 0 & 8.99 & $\begin{array}{l}\text { Firms' expenditure on } \\
\text { environmental protection in } \\
2005 \text {, logged }\end{array}$ \\
\hline SOE_Retain & 1037 & 0.07 & 0.24 & 0 & 1 & $\begin{array}{l}\text { State-owned enterprises founded } \\
\text { before 1992, without } \\
\text { restructuring }\end{array}$ \\
\hline SOE_Restructure & 1037 & 0.08 & 0.27 & 0 & 1 & $\begin{array}{l}\text { State-owned enterprises founded } \\
\text { before 1992, Restructured }\end{array}$ \\
\hline SOE_New & 1037 & 0.09 & 0.28 & 0 & 1 & $\begin{array}{l}\text { State-owned enterprises founded } \\
\text { after } 1992\end{array}$ \\
\hline FIE & 1037 & 0.22 & 0.42 & 0 & 1 & $\begin{array}{l}\text { Firms founded as foreign firms or } \\
\text { joint ventures }\end{array}$ \\
\hline De_novoPrivate & 1037 & 0.55 & 0.50 & 0 & 1 & $\begin{array}{l}\text { Firms founded as domestic private } \\
\text { firms }\end{array}$ \\
\hline Gov_Labor & 932 & 2.36 & 3.37 & 0 & 36 & $\begin{array}{l}\text { No. of government inspections of } \\
\text { labor protection per year }\end{array}$ \\
\hline Gov_Env & 941 & 4.10 & 14.18 & 0 & 365 & $\begin{array}{l}\text { No. of government inspections of } \\
\text { environmental protection per } \\
\text { year }\end{array}$ \\
\hline Client_Labor & 1037 & 0.33 & 0.47 & 0 & 1 & $\begin{array}{l}\text { Whether clients ask the firm to } \\
\text { meet labor standards }\end{array}$ \\
\hline Client_Env & 1037 & 0.51 & 0.50 & 0 & 1 & $\begin{array}{l}\text { Whether clients ask the firm to } \\
\text { meet environment standards }\end{array}$ \\
\hline Log_Employ & 1037 & 5.39 & 1.30 & 0.69 & 11.37 & No. of employees in 2004 , logged \\
\hline Log_Profit & 1037 & 11.41 & 0.44 & 0 & 14.77 & Firms' profit in 2004, logged \\
\hline City & 1037 & & & & & 12 representative cities \\
\hline Industry & 1037 & & & & & 29 sectors in manufacturing \\
\hline
\end{tabular}

sectors for robustness check. There are 29 sectors for all the manufacturing firms in our sample, for which we included 28 dichotomous variables in the statistical analyses. We also controlled for location specific factors, i.e., cities throughout our analysis, using hierarchical linear modeling (HLM), as explained in the section below. Table 1 is a summary description of all the variables used in our data analyses.

\section{Statistical Models}

Because the dataset used in our study contains multilevel data (city and firm levels), hierarchical linear modeling (HLM) is a suitable tool for our analyses (Raudenbush \& Bryk, 2002). We used the following formulas for HLM:

Firm level model: $\Upsilon_{i j}=\beta_{0 j}+\beta_{i j} X_{i j}+r_{i j}$

City level model: $\beta_{0 j}=\gamma_{00}+u_{o j} ; \beta_{\ddot{j}}=\gamma_{i 0}+u_{o j}$ 


$$
\text { Combined model: } Y_{\ddot{j}}=\left(\gamma_{00}+\gamma_{i 0} X_{\ddot{y}}\right)+\left(u_{0 j}+u_{i j} X_{\ddot{j}}+r_{\ddot{j}}\right)
$$

Here, $Y_{i j}$ represents the spending on labor or environmental protection. Model (1) denotes that a firm's labor or environmental protection is influenced by several factors, such as its founding ownership and other firm level controls. Model (2) denotes that the intercepts and slopes in regressions in (1) vary across different cities in China. The city level effects are controlled this way, but we did not use any city level control variables, so there are only a fixed term and a random error term in each equation in Model (2). Model (3) is the combined model of model (1) and (2). In model (3), items within the first parentheses capture the fixed effects, while items within the second parentheses capture the random effects. We used the statistical software Stata 12 command xtmixed to process the data with continuous dependent variables.

\section{RESULTS}

Table 2 presents pairwise correlations between all the variables used. We tested multicolinearity using variance inflation factor (VIF). A common threshold value for VIF is 5 (Studenmund 2001). In our case, all the VIF values of the independent variables are smaller than 3 , indicating that multicollinearity is not a major concern here.

Table 3 reports the results of hierarchical linear models predicting firms' expenditure on labor protection. Only full models are included in the table. Model 1 is to test whether old SOEs without restructuring experience (SOE_Retain) outperformed non-SOEs (FIE and de novo private) in labor protection. Model 1 compares socialist founding ownership effects on firms' current expenditure on labor protection, with SOE_Retain as a reference group. The sign and significance of the coefficients of FIE and de novo private suggest that old SOEs without restructuring experience spent significantly more on labor protection than nonSOEs. In Model 2, old SOEs with restructuring experience were used as a reference group. The sign and significance of the coefficients of FIE and de novo_private suggest that the restructured SOEs spent more on labor protection than non-SOEs. Results in Models 1 and 2 lent support for Hypothesis 1. The differences among various SOEs groups are not significant, which further suggests that founding state ownership serves as a mechanism in preserving organizational imprinting in labor protection. Model 3 tests Hypothesis 2. The sign of the coefficient of FIE and de_novo private is negative and significant, which suggests that new SOEs still outperformed most of private firms and FIEs founded in the same market reform period. It provided support to Hypothesis 2 that argues for the contagious effect of ownership imprinting among firms of the same form or identity.

The organizational imprinting effects hold true regardless of SOEs' different founding periods and their restructuring experience. In a way, the effects of founding ownership triumphed that of the founding stages for SOEs in China. However, 
Table 2. Pairwise correlations of variables

\begin{tabular}{|c|c|c|c|c|c|c|c|c|c|c|c|c|c|}
\hline & 1 & 2 & 3 & 4 & 5 & 6 & 7 & 8 & 9 & 10 & 11 & 12 & 13 \\
\hline Log_Labor & 1 & & & & & & & & & & & & \\
\hline Log_Env & $0.30^{*}$ & 1 & & & & & & & & & & & \\
\hline SOE_Retain & $0.18^{*}$ & $0.07^{*}$ & 1 & & & & & & & & & & \\
\hline SOE_Restructure & $0.08^{*}$ & -0.01 & $-0.10^{*}$ & 1 & & & & & & & & & \\
\hline SOE_New & 0.02 & -0.02 & $-0.09^{*}$ & $0.42^{*}$ & 1 & & & & & & & & \\
\hline FIE & -0.04 & 0.07 & $-0.16^{*}$ & $-0.17^{*}$ & $-0.16^{*}$ & 1 & & & & & & & \\
\hline De_novo Private & $-0.13^{*}$ & $-0.08^{*}$ & $-0.34^{*}$ & $-0.34^{*}$ & $-0.33^{*}$ & $-0.58^{*}$ & 1 & & & & & & \\
\hline Gov_Labor & 0.01 & $0.08^{*}$ & -0.03 & $-0.06^{*}$ & -0.06 & -0.06 & $0.12^{*}$ & 1 & & & & & \\
\hline Gov_Env & -0.04 & $0.22^{*}$ & -0.01 & -0.03 & -0.03 & -0.02 & 0.05 & $0.25^{*}$ & 1 & & & & \\
\hline Client_Labor & -0.04 & $0.07^{*}$ & $-0.07^{*}$ & -0.03 & 0.02 & 0.01 & 0.05 & $0.10^{*}$ & 0.01 & 1 & & & \\
\hline Client_Env & $-0.07^{*}$ & $0.07^{*}$ & -0.05 & $-0.07^{*}$ & -0.03 & $0.08^{*}$ & 0.00 & $0.08^{*}$ & 0.05 & $0.66^{*}$ & 1 & & \\
\hline Log_Employ & $0.60^{*}$ & $0.49^{*}$ & $0.21^{*}$ & $0.07^{*}$ & 0.00 & $0.14^{*}$ & $-0.29^{*}$ & 0.03 & 0.03 & 0.03 & 0.02 & 1 & \\
\hline Log_Profit & $0.16^{*}$ & $0.03^{*}$ & -0.04 & 0.02 & -0.01 & $0.08^{*}$ & -0.05 & 0.00 & 0.02 & -0.01 & 0.01 & $0.24^{*}$ & 1 \\
\hline
\end{tabular}

Notes: Sig. level: * 0.05 . 
Table 3. Hierarchical linear models for predicting firms' spending on labor protection

\begin{tabular}{|c|c|c|c|c|c|c|}
\hline & \multicolumn{2}{|c|}{ Model 1} & \multicolumn{2}{|c|}{ Model 2} & \multicolumn{2}{|c|}{ Model 3} \\
\hline & Coef. & S.E. & Coef. & S.E. & Coef. & S.E. \\
\hline FIE & $-0.83^{* * *}$ & 0.26 & $-0.86^{* * *}$ & 0.26 & $-0.97^{* * *}$ & 0.27 \\
\hline De_novo Private & $-0.16^{*}$ & 0.24 & $-0.19^{*}$ & 0.25 & $-0.30^{*}$ & 0.24 \\
\hline SOE_Retain & (Reference) & & 0.21 & 0.29 & 0.08 & 0.32 \\
\hline SOE_Restructure & 0.30 & 0.27 & (Reference) & & -0.37 & 0.38 \\
\hline SOE_New & -0.09 & 0.29 & -0.04 & 0.29 & (Reference) & \\
\hline Gov_Labor & 0.02 & 0.02 & -0.18 & 0.14 & -0.19 & 0.14 \\
\hline Client_Labor & -0.18 & 0.14 & 0.02 & 0.02 & 0.02 & 0.02 \\
\hline Log_Employ & $1.11^{* * *}$ & 0.06 & $1.10^{* * *}$ & 0.06 & $1.11^{* * *}$ & 0.060 \\
\hline Log_Profit & 0.06 & 0.15 & 0.08 & 0.15 & 0.09 & 0.15 \\
\hline Constant & -1.22 & 1.65 & -1.36 & 1.68 & -1.32 & 1.67 \\
\hline LR Test & $-1597.11^{* * *}$ & & $-1597.45^{* * *}$ & & $-1596.97^{* * *}$ & \\
\hline $\mathrm{N}$ & 785 & & 785 & & 785 & \\
\hline
\end{tabular}

Notes: Sig. level: ${ }^{*} 0.1 ;{ }^{* *} 0.05 ;{ }^{* * *} 0.01$; Base models for LR tests (model deviance test) are models with control variables only; City effect is controlled with HLM.

Table 4. Hierarchical linear models for predicting firms' spending on environmental protection

\begin{tabular}{|c|c|c|c|c|c|c|}
\hline & \multicolumn{2}{|c|}{ Model 4} & \multicolumn{2}{|c|}{ Model 5} & \multicolumn{2}{|c|}{ Model 6} \\
\hline & Coef. & S.E. & Coef. & S.E. & Coef. & S.E. \\
\hline FIE & 0.34 & 0.23 & $0.54^{* *}$ & 0.24 & $0.39^{*}$ & 0.21 \\
\hline De_novo Private & $0.38^{* *}$ & 0.21 & $0.57^{* * * *}$ & 0.22 & $0.42^{* *}$ & 0.19 \\
\hline SOE_Retain & (Reference) & & 0.34 & 0.26 & 0.33 & 0.26 \\
\hline SOE_Restructure & -0.17 & 0.24 & (Reference) & & -0.81 & 0.33 \\
\hline SOE_New & 0.35 & 0.26 & 0.34 & 0.26 & (Reference) & \\
\hline Gov_Env & $0.05^{* * *}$ & 0.01 & $0.18^{* * *}$ & 0.12 & $0.18^{* * *}$ & 0.12 \\
\hline Client_Env & 0.18 & 0.12 & 0.05 & 0.01 & 0.05 & 0.01 \\
\hline Log_Employ & $0.72^{* * *}$ & 0.05 & $0.72^{* * *}$ & 0.05 & $0.71^{* * *}$ & 0.05 \\
\hline Log_Profit & -0.16 & 0.13 & -0.15 & 0.13 & -0.14 & 0.13 \\
\hline Constant & 0.45 & 1.47 & 0.10 & 1.492 & 0.20 & 1.49 \\
\hline LR Test & $-1505.37^{* * *}$ & & $-1504.75^{* * *}$ & & $-1502.72^{* * *}$ & \\
\hline $\mathrm{N}$ & 785 & & 785 & & 785 & \\
\hline
\end{tabular}

Notes: Sig. level: ${ }^{*} 0.1 ;{ }^{* *} 0.05 ;{ }^{* * *} 0.01$; Base models for LR tests (model deviance test) are models with control variables only; City effect is controlled with HLM.

there are differences between de novo FIEs and de novo private firms, because the significance level of the effect of de novo private firms is less salient than that of FIEs. It might be the case that newly founded private firms tended to spend more than FIEs on labor protection to get recognition from the state and general public (Ma \& Parish, 2006). FIEs, on the other hand, mostly coming from Western countries, did not receive such pressure to comply with labor standards.

We applied the same analytical logic to environmental protection in Table 4. Models 4 and 5 test Hypothesis 3. Model 4 takes old SOEs without restructuring experience as a reference group. The signs of coefficients of FIE and de novo private 
are positive, which suggests that non-SOEs spent more on environmental protection than old SOEs. However, the coefficient of FIE is not significant. In Model 5, with all other factors controlled, the signs and coefficients of FIEs and de novo private suggest that these non-SOEs outperformed the restructured SOEs in environmental protection. Together, Models 4 and 5 lend strong support to Hypothesis 3. Similarly, Hypothesis 4 is supported with evidence from Model 6; the newly founded SOEs spent less than non-SOEs in environmental protection.

In labor and environmental protection, there are no significant differences among the sub-categories of SOEs. The major difference is between SOEs and non SOEs. In general, our hypotheses about the persistence of founding imprints and the contagious effect of founding ownership imprints are supported.

\section{Robustness Checks}

To determine whether there is a pattern in the missing values of independent variables, we created a dichotomous variable that takes the value 1 to indicate all the records that are present in the regression models and the value 0 to indicate missing (and thus list-wise deleted) records. We took this dichotomous variable as a dependent variable, and ran a logistic regression with all the independent variables. The results showed that the coefficients of key independent variables were not statistically significant, indicating that list-wise deleted cases are missing at random. So, missing values are not serious problems in our statistical analyses.

We used two methods to show that common method bias is not a major problem in this study. First, the survey was filled out by nine different department managers in a given firm, each in charge of the sections relevant to their job descriptions. The variables used in this study were selected from different sections of the survey and therefore addressed by different managers. Second, we ran factor analyses for all the variables used in a given model, which were not centered on one single factor and therefore indicated that the common methods variance is not a critical problem in our research (Podsakoff, MacKenzie, Lee, \& Podsakoff, 2003).

We also conducted a robustness check using different dependent variables. For example, in addition to investigating firms' spending on CSR related activities, we also ran regressions on firms' provision of medical rooms, preschools, and dining halls for their workers. All these alternative dependent variables yielded similar results for the same set of independent variables.

\section{DISGUSSION}

We examined how a firm's founding ownership affected its current CSR practices in labor and environmental protection, controlling for other institutional factors such as the state and transnational private regulation. Our results showed that SOEs founded during the socialist period still carried their founding ownership imprints of pro-labor practices, and that the strong founding ownership imprints still remained 
even when some SOEs were restructured in their post-founding sensitive period, i.e., the market reform era (H1). In addition, the strong effects of founding ownership imprinting explained why the newly founded SOEs in the market reform period still outperformed private firms and FIEs founded in the same period in labor protection (H2). This result, again, pointed to the strong founding ownership imprinting of SOEs and the relatively weaker effects of subsequent sensitive periods that advocate a market economy. In contrast, environmental protection was not a serious concern before the market reform in China. The following market reform era, however, saw the proliferation of Chinese private firms and FIEs, when environmentalism was introduced but labor market regulation became loosely enforced. This period is no doubt a founding stage for private firms, FIEs, and some new SOEs. The SOEs, regardless of their founding era and restructuring experience, put less effort on environmental protection than private firms and FIEs ( $\mathrm{H} 3$ and H4). For SOEs founded during the socialist period, this sensitive period did not leave a strong mark on their propensities to follow environmental requirements, suggesting that founding period as a particular sensitive period may have greater effects than other sensitive periods.

Organization theorists have advanced our understanding of firm-environment relationship from different angles, each focusing on a contemporary factor (DiMaggio \& Powell, 1983; Hannan \& Freeman, 1977). The organizational imprinting perspective, however, unpacks how organizations are systematically constrained and enabled by the founding stage to shape their current practices, procedures, and strategies. Combining the organizational imprinting perspective and the recent CSR campaign in China has both theoretical and empirical implications. The dramatic changes in China in the past several decades provided an ideal research setting that enables us to investigate socialist imprinting - a particular founding imprint with socialist features - in labor and environmental standards by different ownerships, and to uncover the relative importance of different sensitive periods.

\section{Theoretical and Empirical Implications}

Our research has some important implications. First, our research provided a nuanced understanding of socialist imprinting through a serious consideration of firms' founding ownership and their restructuring experiences. Previous imprinting research focused their analysis lens more at the level of social environment. We, however, restated the importance of firm-level features. As we stated above, the institutional and market environments of the socialist planned economy are very different from those of market capitalism, and are often characterized by rapid change and a mass level of organizational restructuring in market reform. Through testing socialist state ownership imprinting in China, our research showed that transition economies are also the suitable settings for preserving founding imprints. Understanding organizational imprints in transition economies leads to a better 
reading of firms' actual capabilities and deficiencies, and thus provides a foundation for better management and policy-makings. An effective strategy for firms to make transition may consider keeping some historically developed strengths and overcoming their weaknesses in a newly induced market economy.

Secondly, our research showed that although Chinese firms went through different sensitive periods, their founding period was still more important than post-founding periods. In general, organizations are more likely to adopt certain practices legitimatized by institutional environments of their founding period and are less likely to be influenced than other sensitive periods. For SOEs founded during the socialist period, strong state action and mobilization capabilities during that time have characterized the most sensitive period, whose features of labor protection have been imprinted on them. In a comparative sense, the post-socialist market reform, although important in many respects, is less than a sensitive period to reshape those SOEs' pro-labor policies.

In addition, our research extended the growing CSR literature by focusing on the historical origin of CSR practices. Prior CSR research has paid inadequate attention to the fact that various dimensions of CSR are rooted differently in firms' historical development processes. Unlike prior emphasis on firms' ongoing institutional environments, our research shifted the analytic lens onto an organizational imprinting perspective, which enabled us to take the CSR literature one step further by unpacking the different mechanisms that lead the same firms to behave differently with regards to labor versus environmental protection.

\section{Limitations}

Our research has its limitations. First, we used firms' expenditure on environment related activities as a proxy of their compliance with environmental protection. We admit that it is only a rough measurement of the compliance, even though we controlled for the sector effect. The same limitation also applies to our analysis of labor protection. Secondly, we treated SOEs as a focus of our research and take de novo private firms and de novo FIEs as in the same category. Although de novo private firms and de novo FIEs together are fundamentally different from SOEs, there exists subtle difference between them, which suggests that future research could elaborate on a well-designed comparison.

\section{Future Research}

There are a number of related research questions that are worth further investigating. While pro-market policy prescriptions offered to the transition economies coincided with the dominance of neoliberal economic thought and policy techniques in the 1980s and 1990s, protests by laid-off SOE employees in these economies, as well as the financial crisis in the late $2000 \mathrm{~s}$, have given rise to a different view of firms' operating principles, although no alternatives have taken 
over the dominance (Babb, 2013). For example, a reconsideration of completely freemarket arrangements of employment relations has provoked policy and scholarly debates as well as changes in practices. We mainly analyzed the SOE imprinting from 1950s to early 1990s, and those from early 1990s to the mid-2000s. There is emerging an additional sensitive period that is characterized by a nostalgic thought of certain aspects of socialist principles. How we define, interpret, and deal with these alternate views requires a further analysis.

\section{GONGLUSION}

Firms are not only influenced by the ongoing institutional pressures, they are guided by their historical founding features too. Understanding organizational imprints developed in various historical periods leads to a proper diagnosis of firms' actual capabilities and deficiencies, as well as leads to solutions for better management and effective policy makings, especially in studying firms in socialist countries. The unique mobilization and governance style of a socialist state set up a founding organizational feature with the deeply-seated routines and mentalities for firms as SOEs, which means that reforming SOEs will not be an easy task. However, through combining historical and institutional perspectives in studying firms' labor and environmental protection activities, our research suggests that a radical restructuring of SOEs may not be a feasible strategy. Rather, recognizing SOEs' strength in labor protection and incorporating it to their CSR agenda may be a better way of organizational level reformation. In the meanwhile, effective policy-making and management activities need to be found or developed to help SOEs improve their poorer performance in environmental protection. Our research develops organizational imprinting theory; it also lays a foundation for better achieving firms' goals in CSR.

\section{NOTES}

We thank two anonymous reviewers and the editor Chris Marquis for providing helpful comments and suggestions. Special thanks to Joe Galaskiewicz and Mia Raynard for the supportive comments on early drafts of this paper.

[1] We acknowledge that the employment relationship of SOEs was maintained through the discriminative membership based on urban residence. We also understand that the SOE reform in the 1990s removed some social services provision. But it does not mean that the reformed SOEs take no social responsibilities. They still offer many such benefits through purchasing from the marketplace rather than by setting up their own subdivisions in charge of welfare provision. These concerns are legitimate in many respects and deserve a separate account.

\section{REFERENGES}

Babb, S. 2013. The Washington consensus as transnational policy paradigm: Its origins, trajectory and likely successor. Revieze of International Political Economy, 20(2): 268-297.

Baron, J. N., Burton, M. D., \& Hannan, M. T. 1996. The road taken: Origins and evolution of employment systems in emerging companies. Industrial and Corporate Change, 5(2): 239275 . 
Baron, J. N., Hannan, M. T., \& Burton, M. D. 1999a. Building the iron cage: Determinants of managerial intensity in the early years of organizations. American Sociological Revieze, 64(4): 527-547.

Baron, J. N., Hannan, M. T., \& Burton, M. D. 1999b. Engineering bureaucracy: The genesis of formal policies, positions, and structures in high-technology firms. Journal of Laze, Economics, and Organization, 15(1): 1-41.

Bartley, T. 2007. Institutional emergence in an era of globalization: The rise of transnational private regulation of labor and environmental conditions. American Journal of Sociology, 113(2): $297-351$.

Bartley, T., \& Child, C. 2011. Movements, markets, and fields: The effects of anti-sweatshop campaigns on U.S. firms, 1993-2000. Social Forces, 90(2): 425-451.

Beckman, C. M., \& Burton, M. D. 2008. Founding the future: Path dependence in the evolution of top management teams from founding to IPO. Organization Science, 19(1): 3-24.

Biggart, N. W., \& Guillén, M. F. 1999. Developing differences: Social organization and the rise of the auto industries of South Korea, Taiwan, Spain, and Argentina. American Sociological Revieze, 64(5): 722-747.

Boeker, W. 1988. Organizational origins: Entrepreneurial and environmental imprinting at the time of founding. In G .R. Carroll (Ed.), Ecological Models of Organizations: 33-51. Cambridge, MA: Ballinger.

Boeker, W. 1989a. The development and institutionalization of subunit power in organizations. Administrative Science Quarterly, 34(3): 388-410.

Boeker, W. 1989b. Strategic change: The effects of founding and history. Academy of Management Journal, 22(3): 489-515.

Buhr, H., \& Grafström, M. 2004. Corporate social responsibility edited in the business press - Package solutions with problems included. Conference on Corporate Social Responsibility in the Era of the Transforming Welfare State, Florence, Italy.

Burton, M. D., \& Beckman, C. M. 2007. Leaving a legacy: Position imprints and successor turnover in young firms. American Sociological Revieze, 72(2): 239-266.

Campbell, J. L. 2007. Why would corporations behave in socially responsible ways? An institutional theory of corporate social responsibility. Academy of Management Revieze, 32(3): 946-967.

Child,J., \& Tse, D. K. 2001.China's transition and its implications for international business.Journal of International Business Studies, 32(1): 5-21.

China Survey Data Network. 2006. Private sector survey. [Cited 13 September 2010.] Available from URL: http://www.chinasurveycenter.org/csdn_en/DownLoadChannel_new/ detail.aspx?ClassID $=4 \&$ DataID $=8$

Davis, G. F., Whitman, M., \& Zald, M. 2008. The responsibility paradox. Stanford Social Innovation Revieze, Winter: 31-37.

Demsetz, H., \& Villalonga, B. 2001. Ownership structure and corporate performance.Journal of Corporate Finance, 7(3): 209-233.

DiMaggio, P.J., \& Powell, W. W. 1983. The iron cage revisited: Institutional isomorphism and collective rationality in organizational fields. American Sociological Revieze, 48(2): 147160 .

Ding, W. 2011. The impact of founders' professional-education background on the adoption of open science by for-profit biotechnology firms. Management Science, 7(2): 257-273.

Dobbin, F., \& Sutton, J. 1998. The strength of a weak state: The rights revolution and the rise of human resources management divisions. American Journal of Sociology, 104(2): 441-476.

Edelman, L. 1990. Legal environments and organizational governance: The expansion of due process in the American workplace. American Journal of Sociology, 95(6):1401-1440.

Edelman, L. 1992. Legal ambiguity and symbolic structures: Organizational mediation of civil rights law. American Journal of Sociology, 97(6): 1531-1576.

Frazier, M. 2010. Socialist insecurity: Pension and the politics of uneven development in China. Ithaca, NY: Cornell University Press.

Guthrie, D. 1999. Dragon in a three-piece suit: The emergence of capitalism in China. Princeton, NJ: Princeton University Press.

Hanna, M., \& Freeman, J. 1977. The population ecology of organizations. American Journal of Sociology, 82(5): 929-964.

Hannan, M., Burton, M. D., \& Baron, J. 1996. Inertia and change in the early years: Employment relations in young, high technology firms. Industrial and Corporate Change, 5(2): 503-536.

Hoffman, A.J. 2001. From heresy to dogma: An institutional history of corporate environmentalism. Stanford, CA: Stanford University Press. 
Hurst, W. 2009. The Chinese worker after socialism. The China Quarterly, 198: 459-493.

Kalev, A., Shenhav, Y., \& De Vries, D. 2008. The state, the labor process, and the diffusion of managerial models. Administrative Science Quarterly, 53(1): 1-28.

Khanna, T., \& Palepu, K. 2000. The future of business groups in emerging markets: Long-run evidence from Chile. Academy of Management Journal, 43(3): 268-285.

Kogut, B., \& Zander, U. 2000. Did socialism fail to innovate? A natural experiment of the two Zeiss companies. American Sociological Revieze, 65(2): 169-190.

Kriauciunas, A., \& Kale, P. 2006. The impact of socialist imprinting and search on resource change: A study of firms in Lithuania. Strategic Management Journal, 27(7): 659-679.

Lee, G. K. 2007. Against the law: Labor protests in China's rustbelt and sunbelt. Berkeley, CA: University of California Press.

Lin, J. Y., Cai, F., \& Li, Z. 1998. Competition, policy burdens, and state-owned enterprise reform. American Economic Revieze, 88(2): 422-427.

Locke, R. M., Qin, F., \& Brause, A. 2007. Does monitoring improve labor standards? Lessons from Nike. Industrial and Labor Relations Revieze, 61(1): 3-31.

Lockett, A., Moon, J., \& Visser, W. 2006. Corporate social responsibility in management research: Focus, nature, salience and sources of influence. Journal of Management Studies, 43(1): $115-136$.

Lounsbury, M. 2001. Institutional source of practice variation: Staffing college and university recycling programs. Administrative Science Quarterly, 46(1): 29-56.

Lounsbury, M. 2007. A tale of two cities: Competing logics and practice variation in the professionalizing of mutual funds. Academy of Management Journal, 50(2): 289-307.

Lu, F. 1989. Danwei: A unique form of organizations. Social Sciences in China (in Chinese), 1: 71-88.

Ma, D., \& Parish, W. L. 2006. Tocquevillian moments: Charitable contributions by Chinese private entrepreneurs. Social Forces, 85(2): 943-964.

Margolis, J. D., \& Walsh, J. P. 2003. Misery loves companies: Rethinking social initiatives by business. Administrative Science Quarterly, 48(2): 268-305.

Marquis, C. 2003.The pressure of the past: Network imprinting in intercorporate communities. Administrative Science Quarterly, 48(4): 655-689.

Marquis, C., \& Huang, Z. 2010. Acquisitions as exaptation: The legacy of founding institutions in the U.S. commercial banking industry. Academy of Management Journal, 53(6): 1441-1473.

Marquis, C., \& Qian, C. 2013. Corporate social responsibility reporting in China: Symbol or substance? Organization Science, 25(1): 127-148.

Marquis, C., \& Tilcsik, A. 2013. Imprinting: Toward a multilevel theory. Academy of Management Annals, 7(1): 193-243.

McKendrick, D. G., \& Carroll, G. R. 2001. On the genesis of organizational forms: Evidence from the market for disk arrays. Organization Science, 12: 661-682.

National Bureau of Statistics of China. 2010. China Statistical Yearbook. [Cited 13 September 2010.] Available from URL: http://www.stats.gov.cn/tjsj/ndsj/2010/indexch.htm

Pedersen, E. R. 2010. Modeling CSR: How managers understand the responsibilities of business towards society. Journal of Business Ethics, 91(2): 155-166.

Podsakoff, P. M., MacKenzie, S. B., Lee, J. Y., \& Podsakoff, N. P. 2003. Common method biases in behavioral research: A critical review of the literature and recommended remedies.Journal of Applied Psychology, 88(5): 879-903.

Raudenbush, S. W., \& Bryk, A. S. 2002. Hierarchical linear models: Applications and data analysis methods, 2nd ed. Thousand Oaks, CA: Sage.

Schofer, E., \& Hironaka, A. 2005. The effects of world society on environmental protection. Social Forces, 84(1): 25-47.

Simons, T., \& Roberts, P. W. 2008. Local and non-local pre-founding experience and new organizational form penetration: The case of the Israeli wine industry. Administrative Science Quarterly, 53(2): 235-265.

Stinchcombe, A. L. 1965. Social structure and organizations. In J. March (Ed.), Handbook of organizations: 142-193. Chicago, IL: Rand McNally.

Studenmund, A. H. 2001. Using econometrics: A practical guide, 4th ed. Boston, MA: Addison Wesley Longman.

Sullivan, B. N., Tang, Y., \& Marquis, C. 2014. Persistently learning: How small-world network imprints and organizational adaptation affect firm performance. Strategic Organization, 12(3): 180199. 
Tilcsik, A. 2014. Imprint-environment fit and performance how organizational munificence at the time of hire affects subsequent job performance. Administrative Science Quarterly, 59(4): 639-668.

Tilcsik, A., \& Marquis, C. 2013. Punctuated generosity: How mega-events and natural disasters affect corporate philanthropy in US communities. Administrative Science Quarterly, 58(1): 111 148.

Victor, B., \& Cullen, J. 1988. The organizational bases of ethical work climates. Administrative Science Quarterly, 33(1):101-125.

Walder, A. G. 1986. Communist neo-traditionalism: Work and authority in Chinese industry, Berkeley, CA: University of California Press.

Xu, K., \& Li, W. 2012. An ethical stakeholder approach to crisis communication: A case study of Foxconn's 2010 employee suicide crisis.Journal of Business Ethics, 117(2): 371-386.

Yang, G. 2005. Environmental NGOs and institutional dynamics in China. The China Quarterly, 181: 46-66.

Zhao, M. 2012. CSR-based political legitimacy strategy: Managing the state by doing good in China and Russia. Journal of Business Ethics, 111(4): 439-460.

Yi Han (hanyimail@gmail.com) is an associate professor at the Department of Economic Sociology, School of Humanities, Shanghai University of Finance and Economics. His publications involve topics in deviant organizational behavior, labor protection, and organizational design. His current academic interests are economic sociology, cultural sociology, and organizational sociology.

Enying Zheng (ez246@cam.ac.uk) is a research fellow at the Centre for Business Research, Judge Business School, the University of Cambridge. Her work revolves around the intersection of labor market institutions and economic sociology. She has published articles that integrate social networks and organizational imprinting perspectives into labor standards and corporate social responsibility.

Manuscript received: April 17, 2012

Final version accepted: December 3, 2015

Accepted by: Chris Marquis 